\title{
The North structure: evidence for a possible second impact near the Bloody Creek site, Nova Scotia, Canada
}

\author{
Ian Spooner ${ }^{1 *}$, Peir Pufahl ${ }^{1}$, Trevor Brisco ${ }^{2}$, Jared Morrow ${ }^{3}$, Mariella Nalepa $^{4}$, Peter Williams ${ }^{5}$, and George Stevens $^{1}$
}

1. Department of Earth and Environmental Science, Acadia University, Wolfville, Nova Scotia B4P 2R6, Canada

2. Department of Earth Sciences, University of Toronto, Earth Science Centre, 22 Russell St., Toronto, Ontario, M5S 3B1 Canada

3. Department of Geological Sciences, San Diego State University, San Diego, California 92182-1020, USA: Deceased

4. Department of Earth Sciences, Memorial University of Newfoundland, St. John's, Newfoundland A1B 3X5, Canada

5. Department of Physics, Acadia University, Wolfville, Nova Scotia B4P 2R6, Canada

${ }^{\star}$ Corresponding author <ian.spooner@acadiau.ca $>$

Date received: 07 December 2014 Date accepted: 06 January 2015

\begin{abstract}
The North structure is a discontinuous, partially flooded elliptical basin $250 \mathrm{~m}$ in diameter and defined by arcuate scarps. It is located in Annapolis County, Nova Scotia, approximately $1 \mathrm{~km}$ north of the Bloody Creek structure, a possible $400 \mathrm{~m}$-diameter elliptical impact crater. Geophysical surveys indicate that raised scarps border a broadly elliptical basin with depth/diameter ratios similar to those at the Bloody Creek structure. Percussion coring and probing indicated that the basin is in-filled with $3.5 \mathrm{~m}$ of lacustrine sediment and peat overlying post-glacial alluvial sediment and diamicton. Samples collected proximal to the rim of the structure contain kink-bands in feldspar and biotite and possible planar microstructures in quartz and feldspar. The elliptical nature and similar, anomalous morphometries of the North and Bloody Creek structures indicate that two, low-angled, genetically linked impacts may have taken place at the site. Both structures are interpreted to be post-Pliocene $(<2.6 \mathrm{Ma})$, based on the unlikelihood of their preservation during Cretaceous-Paleogene regional peneplanation.
\end{abstract}

\section{RÉSUMÉ}

La structure d'impact du North Group est une cuvette elliptique discontinue et partiellement inondée d'un diamètre de 250 mètres, définie par des escarpements arqués. Elle se situe dans le comté d'Annapolis, en Nouvelle-Écosse, à environ $1 \mathrm{~km}$ au nord de la structure de Bloody Creek, un possible cratère d'impact de forme elliptique mesurant 400 mètres de diamètre. D’après les levés géophysiques, les escarpements soulevés bordent une cuvette largement elliptique dont les rapports entre la profondeur et le diamètre sont semblables à ceux de la structure de Bloody Creek. Les activités de carottage à percussion et de sondage d'exploration ont permis de savoir que l'intérieur de la cuvette était rempli d'une couche de 3,5 mètres de sédiments lacustres et de tourbe, qui recouvrent du diamicton et des sédiments alluvionnaires d’origine post-glaciaire. Le contenu des échantillons prélevés dans le milieu proximal de la bordure de la structure révèle des bandes froissées dans le feldspath et la biotite et de possibles microstructures planaires dans le quartz et le feldspath. Si l'on se fie à la nature elliptique et à la morphométrie anormale similaire des structures du North Group et de Bloody Creek, il se pourrait que deux impacts d'un angle peu prononcé et génétiquement liés aient eu lieu à cet endroit. Les deux structures seraient, d’après les interprétations, postérieures au Pliocène $(<2,6 \mathrm{Ma})$, car les probabilités qu’elles aient été préservées pendant la pénéplanation régionale du Crétacé-Paléogène sont plutôt faibles.

[Traduit par la redaction]

\section{INTRODUCTION}

The interpretation of a possible impact origin for the Bloody Creek structure in Nova Scotia was based on an integrated analysis of geomorphic, geophysical, and pe- trographic data (Stevens 1995; Spooner et al. 2009). Aerial photographs taken before the Bloody Creek structure site was flooded reveal a prominent elliptical rim $(0.42 \mathrm{~km} \times$ $0.35 \mathrm{~km}$ ), and geophysical surveys confirmed a $5 \mathrm{~m}$-deep depression in-filled with post-glacial lacustrine and wet- 
land sediments. Petrographic analysis revealed planar deformation features broadly supportive of shock metamorphism (Spooner et al. 2009). Here we present evidence for an additional elliptical impact feature in Nova Scotia, located $1 \mathrm{~km}$ north of the Bloody Creek structure and hence termed the North structure.

\section{LOCATION AND GEOLOGY}

The North structure is located in Annapolis County, Nova Scotia, approximately $10 \mathrm{~km}$ south of Bridgetown ( $44^{\circ} 45^{\prime} 40^{\prime \prime} \mathrm{N}, 65^{\circ} 14^{\prime} 40^{\prime \prime} \mathrm{W}$; Fig. 1). Both it and the nearby Bloody Creek structure are currently submerged 1 to $2 \mathrm{~m}$ below the Dalhousie Lake reservoir, a hydroelectric development built in the early 1980s. Access is, therefore, limited to either diving, draining of the reservoir, or atypical seasons of low water level.

Both the North and Bloody Creek structures are located within the South Mountain Batholith (ca. 381-370 Ma), a peraluminous granitoid suite that underlies approximately half of southern Nova Scotia (McKenzie and Clarke 1975; Reynolds et al. 1987; MacDonald et al. 1992; MacDonald 2001). Specifically, they are located within the Scrag Lake biotite monzogranite pluton in which quartz, K-feldspar, plagioclase, and biotite are the major mineral constituents (MacDonald 2001). The batholith intruded the Lower Palaeozoic metasedimentary rocks of the Goldenville, Halifax, and Rockville Notch groups (MacDonald 2001; White 2010a, b, 2012).

The glacial history of Nova Scotia is complex. The study

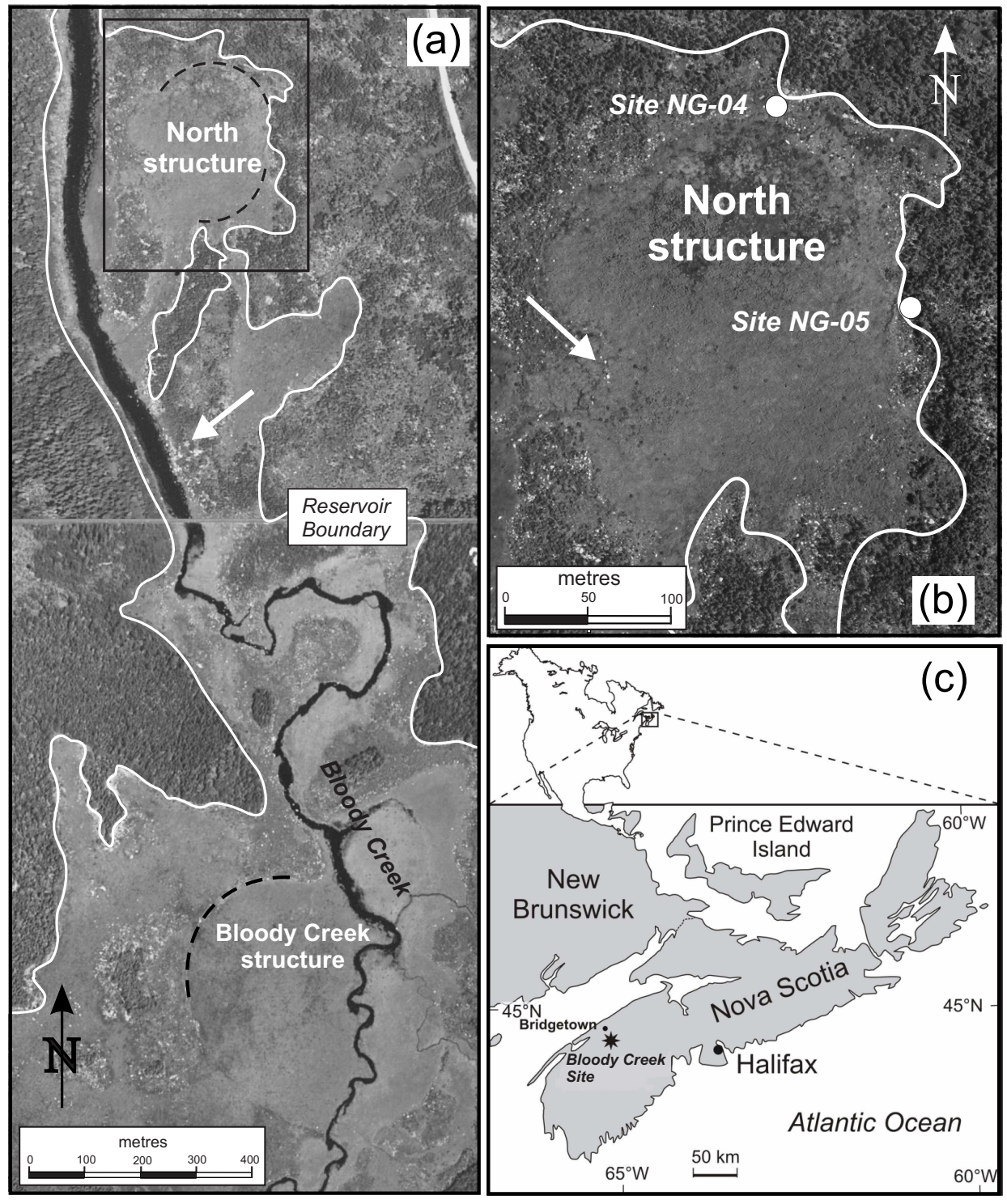

Figure 1. (a) Part of aerial photograph A-77313-62 taken in July, 1977, before the region was flooded for hydroelectric development showing the locations of the North and Bloody Creek structures, located within a fen flanked by low wooded hills. The white dots (e.g., white arrow) are glacial erratics, in some cases more than $3 \mathrm{~m}$ in height. (b) Enlarged view of the North structure. NG-04-4B and NG-05-A are locations where bedrock granite samples were collected for petrographic study. White arrow indicates a large glacial erratic, as in (a). (c) Location map showing area of study. 
site was likely ice-covered during Illinoian time and from the Early to Late Wisconsinan, ca. $75000-14600$ cal. BP (Stea and Grant 1982). By $16700 \mathrm{cal}$. BP the pervasive ice cover had begun to wane and by $14,000 \mathrm{cal}$ BP the study site was likely ice free, although a local ice cap may have persisted until about 11000 cal. BP (Stea and Mott 1998). The till in the study area is generally thin $(<5 \mathrm{~m}$ thick) and is characterized by a sandy matrix with angular stones and boulders derived from local bedrock (Spooner et al. 2009). Bedrock exposure is poor due to till, lake, wetland and forest cover, but, where present, is glacially sculpted. Roche moutinée and associated lee side plucking features are common, indicating that Wisconsinan glacial bedrock erosion was likely substantial.

\section{ANALYTICAL TECHNIQUES}

Surface morphology of the North structure was examined using 1:10 000-scale colored aerial photographs from 1977 (pre-flooding), and subsurface morphology was examined through geophysics, percussion coring, and sediment probing. Geophysical surveys were conducted by boat using a $33 \mathrm{KHz}$ SyQuest Hydrobox single beam echo sounder, and a $10 \mathrm{KHz}$ SyQuest StrataBox single beam echo sounder. The Hydrobox is capable of producing sediment strata resolution in very fine-grained sediment, the Stratabox is a high- resolution marine sediment imaging instrument capable of delivering detailed marine sediment strata resolution with bottom penetration of up to $40 \mathrm{~m}$. The resulting sub-bottom profiles allowed extrapolation of core and sediment probing data to the entire North struc- ture basin and were used to compare the morphometry of the North structure basin to that of the Bloody Creek structure (Fig. 2).

Resolution of the post-glacial infill stratigraphy of the North structure was accomplished using percussion coring and probing. Two percussion cores were retrieved from the center of the North structure following procedures outlined by Reasoner (1993). Percussion coring was accomplished when the reservoir surface was frozen as the ice acts as a stable coring platform. This method of coring was developed primarily for lake sediment sampling and is effective in retrieving continuous cores of unconsolidated sediment. Retrieval of consolidated or compacted sediment is limited. Once obtained, the cores were frozen and split in the lab with a diamond rock saw. All analyses were carried out on Core 2 because this core was taken closest to the center of the structure and is likely most representative of the sediment stratigraphy at the site. Core 2 was divided into distinguishable stratigraphic units based on grain size, colour, and composition. Sediment probing was carried out to ascertain the minimum thickness of the post-glacial infill sediments to aid in geophysical interpretations. Probing was performed half-way across the long axis and short axis of the North structure using a $4 \mathrm{~m}$-long stainless steel rod while standing in an anchored boat. The depth to which the rod penetrated the lake sediments is inferred to mark minimum basin infill thickness.

A two-stage bedrock sampling program was implemented. The first stage involved sampling bedrock from North structure scarp-proximal settings; however, it was found that the submerged structure rims restricted direct access

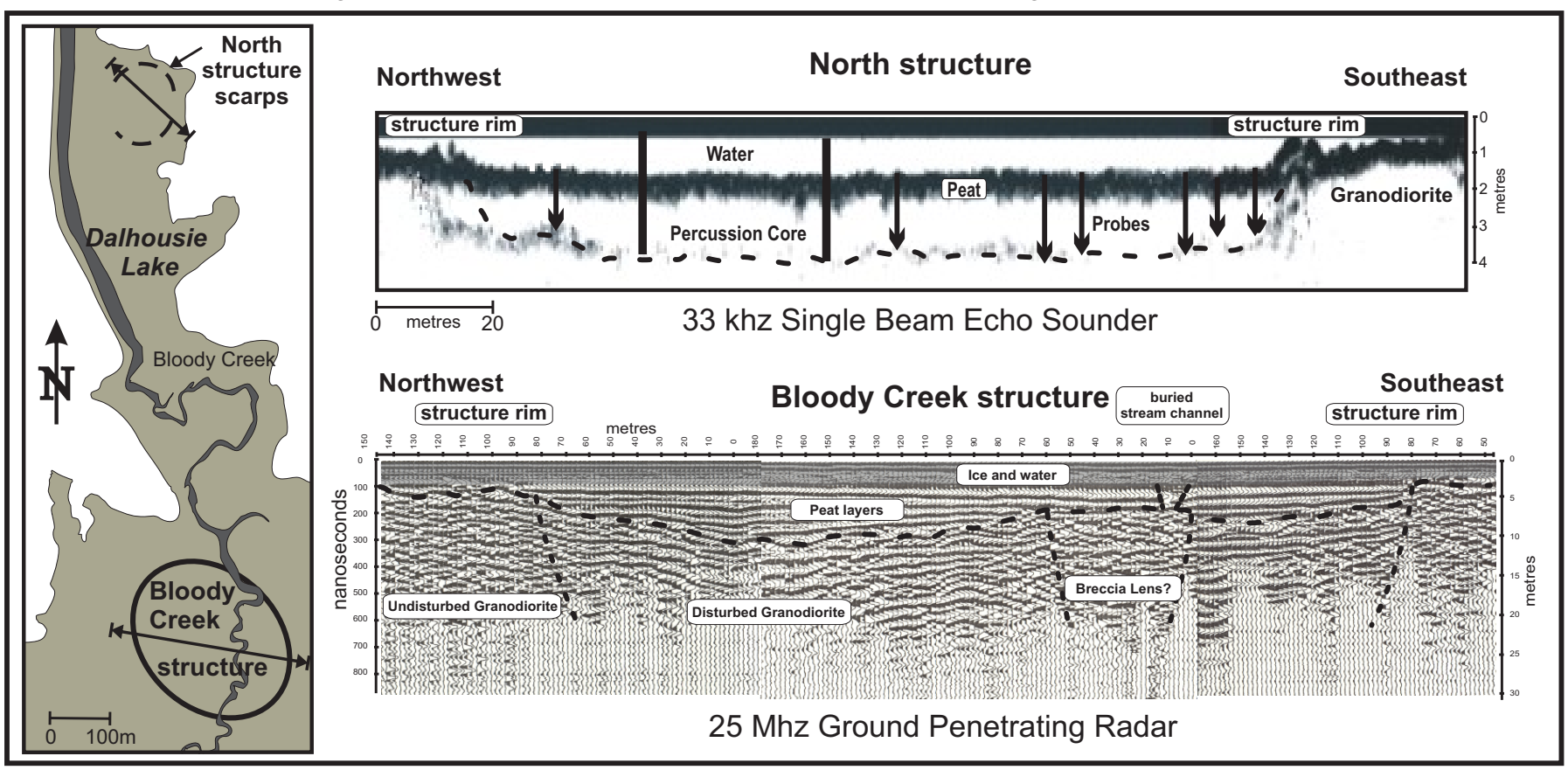

Figure 2. Survey and interpretation of the morphometry of the North structure depression and, for comparison, the Bloody Creek structure depression. Sub-bottom sonar traverses were obtained when the sites were flooded. $33 \mathrm{khz}$ sonar, probing and percussion coring confirm the crater morphometry of the North structure and its similarity to the Bloody Creek structure. Both structures are infilled with post-glacial peat and lacustrine sediments. 
to the scarps (Fig. 1). The second stage involved collecting a random suite of bedrock samples from elsewhere in the Scrag Lake pluton for comparison to samples collected close to the scarp. Thin sections were prepared from the samples and examined visually for evidence of shock metamorphism using a Nikon Optiophot-Pol microscope.

\section{RESULTS}

Aerial photographs taken before the area was flooded indicate that the North structure is an elliptical depression approximately $88 \mathrm{~m}$ diameter characterized by low relief, discontinuous bedrock scarps that border a wetland devoid of outcrop (Figs. 1, 2). Like the Bloody Creek structure, the North structure has an elliptical "rim" with a length to width ratio of 1.2 although the apparent long axis of the structure is oriented N-S in contrast to the NW-SE orientation of the long axis of the Bloody Creek structure (Fig. 1). Aerial photographs indicate that the wetland is almost completely devoid of glacial erratics that are common elsewhere in the study area (Fig. 1). The single beam echo sounding, probing and percussion coring surveys indicate that the wetland sediments at the center of the structure extend to a depth of $3.5 \mathrm{~m}$. The percussion coring of the basin further showed that coarse diamicton is overlain by coarse, granite-rich, moderately sorted sediment which, in turn, is overlain by alternating layers of gyttja and wetland sediment.

Thin sections of bedrock samples taken from random locations in the Scrag Lake pluton outside of the North structure consist of medium- to coarse-grained hypidiomorphic biotite monzogranite. Quartz is generally clear, with sweeping, undulatory extinction and irregular randomly orientated fractures. In contrast, samples collected from bedrock

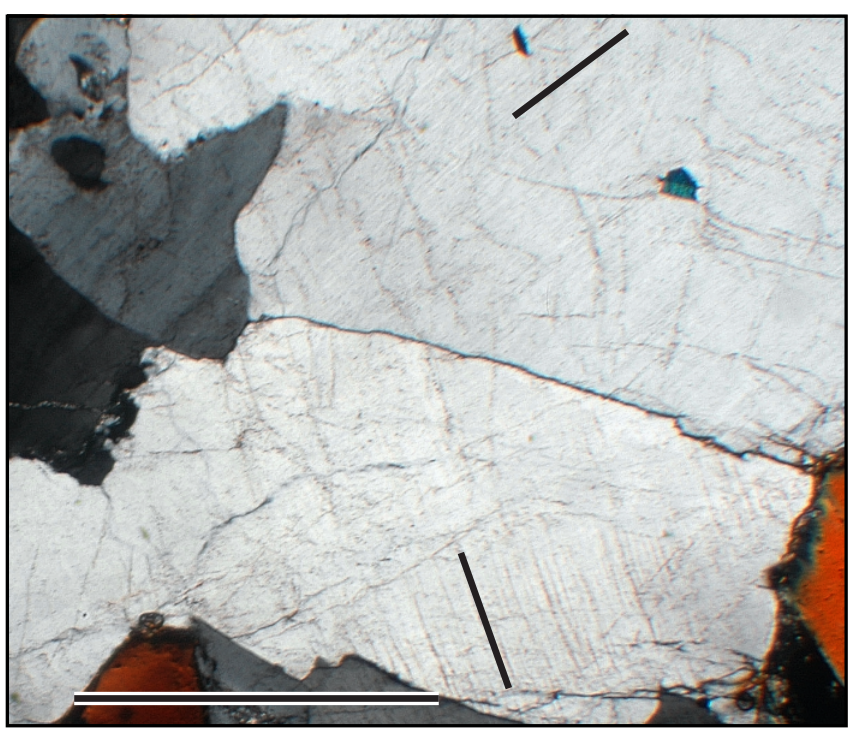

Figure 3. Photomicrograph of quartz in biotite monzogranite from the Scrag Lake pluton showing two sets of possible planar deformation features. The direction of each possible set is indicated by the black line. Sample NG$05-\mathrm{A}$, plane-polarized light. Bar scale is $0.5 \mathrm{~mm}$. on the northeastern crest of the North structure scarp (Fig. 1) contain common subplanar to planar microstructures in quartz and feldspar. These structures consist of sets of thin sub-parallel fractures, spaced approximately 100 to $400 \mu \mathrm{m}$ apart (Figs. 3, 4). Also present are rare decorated planar deformation features in quartz (Fig. 5), kink-bands in feldspar and biotite (Fig. 6) and common grain mosaicism. These microstructures are most abundant in samples from closest to the North structure scarp rim.

\section{INTERPRETATION}

Aerial photographs, geophysical data, and coring and probing data support the interpretation that the North structure is an elliptical, shallow basin that has been partially in-filled with post-glacial sediments. Field observations show that the structure rim is granite and single beam echo sounding data (Fig. 2) indicate that the granite or coarse diamicton extends underneath the North structure and is overlain by about $2 \mathrm{~m}$ of unconsolidated material. Percussion coring revealed a sedimentary succession that is consistent with moderately sorted, texturally mature sediment, interpreted to be fluvial, overlain by alternating lacustrine and fen sediment. The fluvial sediment was likely deposited during the mid-Holocene climate optimum by lateral migration of Bloody Creek before the wetland developed (Fig. 1).The wetland sediment that in-fills the structure was likely deposited during the Late Holocene (ca 3000 BP- Present) when wetter conditions and rising water table resulted in flooding of the depression (Spooner $e t$ al. 2014). The genesis of the basal diamicton is uncertain. Though glacial till is to be expected, the retrieval of only a very small sample by the percussion coring system pre-

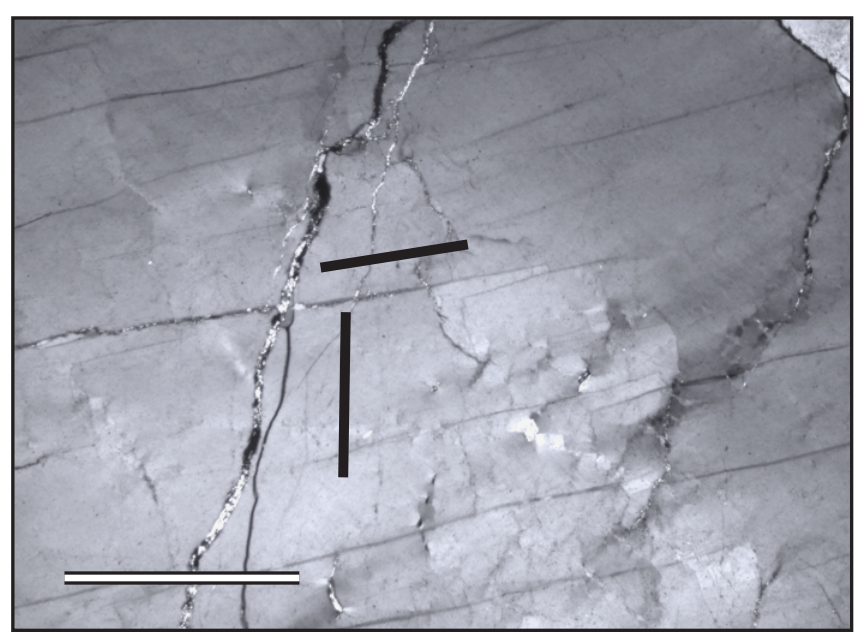

Figure 4. Photomicrograph of quartz in biotite monzogranite from the Scrag Lake pluton showing two possible directions of planar microstructures, as indicated by black lines. Sample NG-04-2B, plane polarized light. Bar scale is $0.1 \mathrm{~mm}$. 


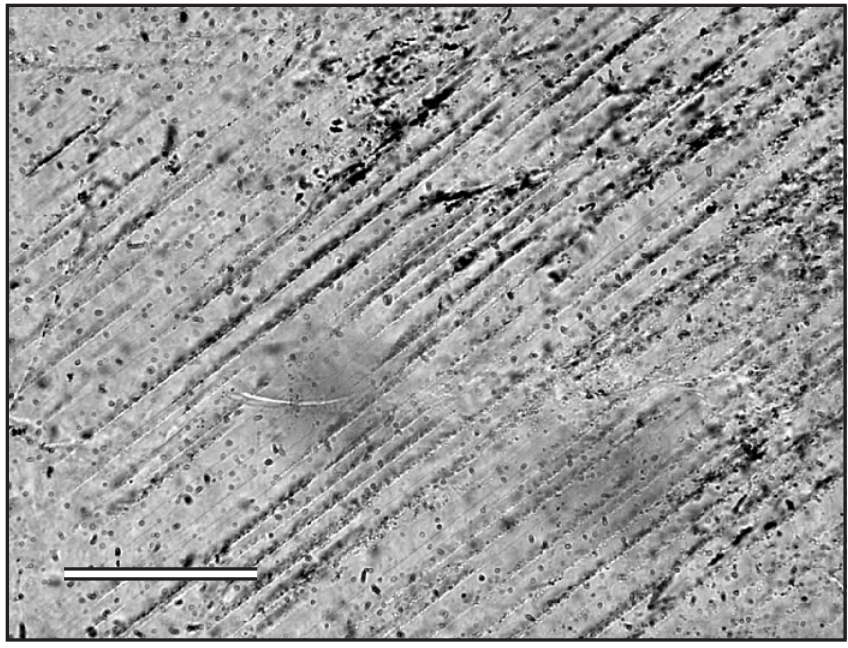

Figure 5. Photomicrograph of quartz in biotite monzogranite from the Scrag Lake pluton showing possible decorated planar to subplanar microstructures. Sample NG-04-4B, plane-polarized light. Bar scale is $0.1 \mathrm{~mm}$.

cluded genetic determination. The lack of glacial erratics in the North structure depression is unusual. It is possible that post-glacial landscape evolution, in particular lateral erosion by Bloody Creek during the early and Mid-Holocene, may have reworked any large erratics and produced the coarse gravel that was noted above the diamicton in the percussion cores. It is also possible that the structure postdates active, erosive glaciation (Spooner et al. 2009).

The samples taken from the rim of the structure show a suite of features (kink banding, planar microstructures, grain mosaicism) that, in themselves are not diagnostic of impact shock. Tectonically formed (sub-) planar microstructures in quartz, such as deformation lamellae and healed fractures can appear similar to shock-induced planar-deformation features, especially when viewed using a light microscope (Hamers 2013). However, comparison with a suite of samples from elsewhere in the Scrag Lake pluton demonstrates that planar microstructures (some with possible decoration), kink banding, and grain mosaicism occur only in samples from the rim of the North structure and are similar to petrographic features observed in samples from the rim of the Bloody Creek structure.

\section{DISCUSSION}

The North structure and the Bloody Creek structure are morphometrically, geophysically, and petrographically similar. Both are characterized by low-lying granite scarps that distinctly outline partially in-filled shallow basins. Although the rim of the Bloody Creek structure is continuous and forms a nearly perfect geometric ellipse, the North structure rim is not continuous but can be extrapolated to an elliptical form. They have similar diameter-depth ratios (as measured from the height of the rim to the top of the granite/diamicton) and long axis-short axis ratios. Samples

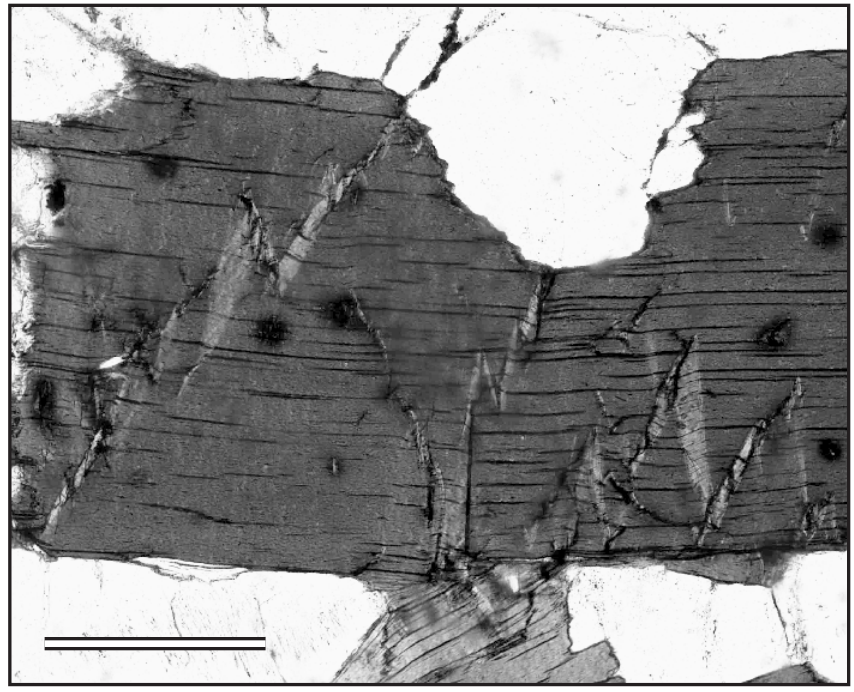

Figure 6. Photomicrograph of biotite in biotite monzogranite from the Scrag Lake pluton showing kink banding. Sample NG-04-4B, plane-polarized light. Bar scale is $0.5 \mathrm{~mm}$.

collected at or near the scarps from both structures contain a similar suite of petrographic features distinct from those in samples collected from the surrounding country rock. Collectively, these features suggest that both structures might be of impact origin, although the evidence for planar deformation features in quartz in the North structure samples is not as clear as in samples from the Bloody Creek structure.

Sampling conditions, post-impact erosion and the conditions under which impact occurred may all have influenced the development and preservation of petrological evidence of impact-related shock in the North structure (Robertson and Grieve 1977). Both the low depth-to-diameter ratio and the lack of strong evidence of planar deformation features in quartz may be a result of considerable post-impact erosion. Both the North structure and nearby Bloody Creek structure are located on the Atlantic Uplands Peneplain. Late Cretaceous to Pliocene erosion of the peneplain is thought to have resulted in the offshore deposition of 1500 $m$ of sand and gravel implying very significant erosion at both sites (Grant 1994; Stea and Pullen 2001; Wade and MacLean 1990). Peneplanation, therefore, likely pre-dated the formation of both structures because such large-scale erosion would have destroyed basin morphometry. These observations infer a post-Pliocene $(<2.6 \mathrm{Ma})$ age for both structures.

Preservation of scarps at the North and Bloody Creek structures through subsequent Pleistocene glacial erosional processes is also problematic. Wisconsinan glacial erosion was significant at the site as indicated by glacial striae, roche moutinée, lee side plucking features and numerous large erratics (Spooner et al. 2009). However, preservation of pre-Pleistocene saprolites beneath till to thicknesses of $<1-6 \mathrm{~m}$ at sites within $10 \mathrm{~km}$ of the study site suggests that glacial erosion processes were not uniform in the region 
(O’Beirne-Ryan and Zentilli 2003). Alternatively, the wellpreserved scarps and low depth-diameter morphometry for both the North Bloody Creek structures might possibly be the product of impact onto thin, stagnant glacial ice (Spooner et al. 2009). Such a scenario may have resulted in the dissipation of much of the impact energy into the ice, resulting in the low diameter-to-depth ratio of the craters. Numerical simulations of crater formation on Mars (Senft and Stewart 2008) suggests that variations in morphometry of shallow craters may be explained by modification of crater excavation and collapse processes by the presence of ice overlying target rock. If the Bloody Creek and North structures were the result of impact onto glacial ice, then the ice would have had to be thin in order for impact to be resolved in the underlying granite (Brisco 2010). Thin, non-erosive ice would also account for the high degree of preservation of the structure rims on an otherwise glacially sculpted and eroded landscape. Such conditions are speculated to have prevailed during the waning stage of Wisconsinan deglaciation, $14,000 \mathrm{cal} \mathrm{yr} \mathrm{BP}$ to $12,000 \mathrm{cal}$. BP (Stea and Mott 1998).

The elliptical scarps and low depth-to-diameter ratio for both the North and Bloody Creek structures suggest a low-angled impact (Elbeshausen et al. 2013; Pierazzo and Melosh 2000; Fig. 1). If confirmed as impact features these two structures may serve as relatively rare examples of lowangled impact into a homogeneous substrate (granite). It is also possible that the two features might be contemporaneous. However, the orientation of the long axes of the two structures appears to be different and suggests that if the structures were formed by one impact event, then a simple model (e.g., Rio Curato crater field, Schultz and Lianza 1992; Suvasvesi South structure, Buchner et al. 2009) will not be adequate. The argument for double impact at the Bloody Creek site might be compared to the discussion of double impact at Flaxman and Crawford site in South Australia (Haines et al. 1999; Haines 2005). At the Flaxman and Crawford site, poor outcrop exposure and possible post-impact tectonism obscure the association between observed, definitive petrographic indications of impact shock and the morphological record of impact and have resulted in the structures being considered as "possible" rather than "confirmed" impact sites. The morphology of both the North structure and the Bloody Creek structure strongly suggest an impact origin. Elliptical basin features in granite are unknown and the apparent post-Pliocene age of both structures precludes a tectonic mechanism for the elliptical shape. What is lacking from the North and Bloody Creek sites is a convincing petrographic record of shock metamorphic effects, a problem that clearly needs further investigation. The location of the structures in a shallow reservoir requires drilling to adequately sample within and below the diamicton.

\section{CONCLUSIONS}

The North structure is outlined by 1 to $2 \mathrm{~m}$-high arcuate scarps that distinctly outline a 250-m diameter shallow, elliptical basin. Morphometric similarities between the North structure and the Bloody Creek structure $1 \mathrm{~km}$ to the south suggest that low-angled, double impact may have taken place at the site. The age is not well constrained but appears to be $<2.6 \mathrm{Ma}$ based on the unlikelihood of their preservation during Cretaceous-Paleogene regional peneplanation. Bedrock samples from the vicinity of the North structure contain planar deformation and other petrographic features broadly consistent with those observed in samples from the Bloody Creek structure but not diagnostic of shock metamorphism. Collectively the observations indicate that the North structure, like the Bloody Creek structure, is a possible impact site deserving of more detailed field and petrographic investigation.

\section{ACKNOWLEDGEMENTS}

The authors thank the Natural Science and Engineering Research Council of Canada (NSERC) and the Geological Survey of Canada (contribution 200080731) for funding this research. Luke Marshall and Don Osburn provided support at the site. Edward King assisted with geophysical surveys. Thin sections were prepared by Don Osburn and Pam Frail, Acadia University. We thank M. Schmieder, E. Buchner, S. Barr and two anonymous reviewers of earlier versions of this manuscript for their helpful comments that significantly improved the manuscript. This paper is dedicated to the Memory of Jared Morrow; he will be missed by many.

\section{REFERENCES}

Brisco, T.H. 2010. A possible multiple impact crater site in southwestern Nova Scotia, Canada. Unpublished B.Sc. honours thesis, Acadia University, Wolfville, Nova Scotia, $54 \mathrm{p}$.

Buchner, E., Schmieder, M., Schwarz, W.H., Trieloff, M., Moilanen, J., Öhman, T. and Stehlik, H. 2009. A Proterozoic ${ }^{40} \mathrm{Ar} /{ }^{39} \mathrm{Ar}$ age for the Suvasvesi South structure (Finland). MetSoc 72, abstract no. 5076.

Elbeshausen, D., Wünnemann, K. and Collins, G.S. 2013. The transition from circular to elliptical craters. Journal of Geophysical Research: Planets, 118, pp.1-15. http:// dx.doi.org/10.1002/2013JE004477

Grant, D.R. 1994. Quaternary Geology, Cape Breton Island, Nova Scotia. Geological Survey of Canada, Bulletin 482, 172 p. http://dx.doi.org/10.4095/194812

Haines, P.W. 2005. Impact cratering and distal ejecta: the Australian record. Australian Journal of Earth Sciences, 52, pp. 481-507. http://dx.doi. org/10.1080/08120090500170351

Haines, P.W., Therriault, A.M. and Kelley, S.P. 1999. Evidence for mid-Cenozoic(?) low-angle multiple impacts 
in South Australia. Meteoritics and Planetary Sciences, 34, pp. A49-A50.

Hamers, M.F. 2013. Identifying shock microstructures in quartz from terrestrial impacts: new scanning electron microscopy methods. Unpublished Ph.D. Dissertation. Universiteit Utrecht, Germany, 191 p.

MacDonald, M.A. 2001. Geology of the South Mountain Batholith, southwestern Nova Scotia. Nova Scotia Department of Natural Resources, Mineral and Energy Branch, Open File Report ME 2001-2, 320 p.

MacDonald, M.A., Corey, M.C., Ham, L.J., and Horne, R.J. 1992. An overview of recent bedrock mapping and follow-up petrological studies of the South Mountain Batholith, southwestern Nova Scotia, Canada. Atlantic Geology, 28, pp. 7-28.

McKenzie, C.B. and Clarke, D.B. 1975. Petrology of the South Mountain Batholith, Nova Scotia. Canadian Journal of Earth Sciences, 12, pp. 1209-1218. http:// dx.doi.org/10.1139/e75-110

O'Beirne-Ryan, A.M. and Zentilli, M. 2003. Paleoweathered surfaces on granitoids of southern Nova Scotia; paleoenvironmental implications of saprolites. Canadian Journal of Earth Sciences, 40, pp. 805-817. http:// dx.doi.org/10.1139/e03-016

Pierazzo, E. and Melosh, H.J. 2000. Understanding oblique impacts from experiments, observations and modeling. Annual Reviews of Earth and Planetary Science, 28, pp. 141-167. http://dx.doi.org/10.1146/annurev. earth.28.1.141

Reasoner, M.A.1993. Equipment and procedure improvements for a lightweight, inexpensive percussion core sampling system. Journal of Paleoclimatology, 8, pp. 273-281.

Reynolds, P.H., Elias, P., Muecke, G.K. and Grist, A.M. 1987. Thermal history of the southwestern Meguma zone, Nova Scotia, from a ${ }^{40} \mathrm{Ar} /{ }^{39} \mathrm{Ar}$ and fission track dating study of intrusive rocks, Canadian Journal of Earth Sciences, 24. pp. 1952-1965. http://dx.doi. org/10.1139/e87-186

Robertson, P.B. and Grieve, R.A.F. 1977. Shock attenuation at terrestrial impact structures. In Impact and explosion cratering. Edited by D.J. Roddy, R.O. Pepin, and R.B. Merrill. New York, Pergamon Press, pp. 687-702.

Schultz, P.H. and Lianza, R.E. 1992. Recent grazing impacts on Earth recorded in the Rio Cuarto crater field, Argentina. Nature, 355, pp. 234-237. http://dx.doi. org/10.1038/355234a0

Spooner, I.S., Stolze, S., Martin, B., Robichaud, A., Herman, T., Mockford, S., Caverhill, B., Mazzucchi, D. and White, H. 2014. A 10,000-year record of environmental change from Blanding's turtle (Emydoidea blandingii) habitat at Pleasant River Fen, Nova Scotia, Canada. Wetlands, 34, pp. 1145-1158. http://dx.doi.org/10.1007/ s13157-014-0573-7
Spooner, I., Stevens, G., Morrow, J., Pufahl, P., Grieve, R., Raeside, R., Pilon, J., Stanley, C., Barr, S., and McMullin, D. 2009. Identification of the Bloody Creek structure, a possible bolide impact crater in southwestern Nova Scotia, Canada. Meteoritics \& Planetary Science, 44, pp. 1193-1202. http://dx.doi.org/10.1111/j.1945-5100.2009. tb01217.x

Senft, L.E. and Stewart, S.T. 2008. Impact crater formation in icy layered terrains on mars; proceedings of the workshop, bridging the gap II; effect of target properties on the impact cratering process, Meteoritics \& Planetary Science, 43, pp. 1993-2013. http://dx.doi. org/10.1111/j.1945-5100.2008.tb00657.x

Stea, R.R. and Grant, D.R. 1982. Pleistocene geology and till geochemistry of southwestern Nova Scotia (Sheets 7 and 8). Nova Scotia Department Mines and Energy Map 82-10, scale 1:100 000.

Stea, R.R. and Pullan, S.E. 2001. Hidden cretaceous basins in Nova Scotia. Canadian Journal of Earth Sciences, 38, pp. 1335-1354. http://dx.doi.org/10.1139/e01-023

Stea, R.R. and Mott, R.J. 1998. Deglaciation of Nova Scotia: Stratigraphy and chronology of lake sediment cores and buried organic sections. Géographie Physique et Quaternaire, 52, pp. 3-21. http://dx.doi. org/10.7202/004871ar

Stevens, G.R. 1995. Meteor Crater, Nova Scotia. The Journal of the Royal Astronomical Society of Canada, 89, pp.111-113.

Wade, J.A. and MacLean, B.C. 1990. Aspects of the Geology of the Scotian Basin from recent seismic and well data; the geology of the southeastern margin of Canada. In Geology of the continental margin of Eastern Canada. Geological Survey of Canada, Geology of Canada no.2, pp.190-238.

White, C.E. 2010a. Pre-Carboniferous bedrock geology of the Annapolis Valley area (NTS21A/14, 15, and 16; $21 \mathrm{H} / 01$ and 02 ), southern Nova Scotia. In Mineral Resources Branch, Report of Activities 2009. Edited by D.R. MacDonald. Nova Scotia Department of Natural Resources, Report 2010-1, pp. 137-155.

White, C.E. 2010b. Stratigraphy of the Lower Paleozoic Goldenville and Halifax groups in the western part of southern Nova Scotia. Atlantic Geology, 46, pp. 136154. http://dx.doi.org/10.4138/atlgeol.2010.008

White, C.E. 2012. Overview map showing locations of bedrock geology maps for the southwestern area of Nova Scotia. Nova Scotia Department of Natural Resources, Minerals Resources Branch, Open File Map 2012-076, scale 1:250 000.

Editorial responsibility: Sandra M. Barr. 